\title{
The Trapped Critique of Critical Media Practices in Protest Movements: A Review of Anne Kaun's “Crisis and Critique”
}

\author{
Yu Xiang \\ University of Westminster, London, UK, yu.xiang@my.westminster.ac.uk
}

\begin{abstract}
This article is a review of Anne Kaun's (2016) book Crisis and Critique: A Brief History of Media Participation in Times of Crisis.
\end{abstract}

Keywords: Anne Kaun, Crisis and Critique, media participation

The burst of energy around the Arab Spring in the Middle East and Occupy Wall Street (OWS) actions in the United State have sparked off many discussions among social activists and academics on the relationship between digital social media and social changes, and indeed the more recent Anti-Trump demonstrations following the presidential elections are another example. Amongst all the discursive discussions on the topic, though there exist insightful critics regarding the substance of social media constrained by its relationship with the capitalist means of production, most are focusing exclusively on the role of social media itself in organising and escalating protests in this contemporary digital age. The lack of an historical perspective has led to a problematic 'media-centric' tendency of 'temporality' in media studies, which endangers the discipline by letting it become engulfed in the constant emergence of new terms and new theories, while the focus on the essential issue of social inequality caused by ever-growing global capitalism has been ignored.

Anne Kaun's new book Crisis and Critique is, therefore, an excellent and timely critical contribution to fill this void. It provides in-depth analyses and debates about protests and related media practices from three different ages of economic crises in the recent contemporary history of America: "the Great Depression in the early 1930s; the fiscal and oil crisis in the 1970s; and the Great Recession in 2007/2008" (5). Kaun analyses the development and changes of media technologies and practices in those protests from the three dimensions of time, space and speed to further discuss "a problematic disconnect between regimes of time established by media technologies such as social media and time of political practices" (4). In her words, "[c]ombining an archaeological analysis with protest activism allows us to develop a media-specific analysis that is at the same time media-centred, but not mediacentric" (31).

Kaun opens her arguments in the first chapter by addressing the two crucial concepts in the title of the book - Crisis and Critique. Economic crisis is, of course, a perpetual feature of capitalism, as manifested in the three cases of economic crises in America, which is at the same time also a "critical juncture ... potentially mark[ing] a state of exception" (17). "Large-scale economic crises and their consequences have this potential for structural changes" (32). Meanwhile, she suggests, social critique in the form of protests and critical media practices creates room for social changes. However, the alternative proposed by critique is not thoroughly opposite to the object of critique. The development of technologies that critical media practices are based on is inevitably embedded in the history of capitalism. That is to say, "his- 
tory is a dialectical process oscillating between the agencies of subjects in relation to given conditions" (Ibid.). In the following three chapters Kaun provides us with a multi-layered study through abundant historical details on critical media practices in the protests of three different historical epochs, on the dialectical relation between media activity in protests as critique, and the development of media technologies boosted by neoliberal capitalism.

In Chapter 2, Kaun talks about "the temporality of protest media practices", as indicated by the title (37). The temporality of media technologies is investigated through analyses of three historical protests on three levels, "namely media production, content distribution and media consumption" (38). She shows how, from mimeograph machine to Internet-based social media, the participation of protesters into media practices is becoming increasingly individualised. What's more worrying, she promotes, is that the shift "from effortful mechanical speed to perpetual flow and effortless, digital immediacy" (57) contributes to the acceleration of communicative capitalism, which indicates that the "exchange value of messages dominates, rather than the use value" (54). Content, therefore, becomes irrelevant. This logic of communicative capitalism "stand[s] in contrast to" "the time-consuming practices of participatory democracy" (56). However, time is not the only thing that is compressed in the fast capitalist society: so is space.

It is noticeable that, as indicated in Chapter 3 on "protest space", in the 1930s the protest movements of unemployed workers were physical collectives with face-toface encounters, while in the 1970s, with the emergence of new media platforms like television, the mobilisation of supporters for protest movements became hybrid (75). In the case of OWS, though spatial protest movements against the neoliberal city are still crucial, the central role of media savviness in increasing online support for the movement led to a decline of "common public spaces" (Ibid.). The shift from space bias to hyper-space bias (72-4), along with the developing media technologies of protests in history, proves a point that "[t]he ideology of annihilation of space is based on new temporalities and acceleration in the production, distribution and consumption of content through social media" (Virilio, 1986, 77).

Hence, the essential issue behind the problematic conceptions of time and space in critical media practices of protest movements against accelerated capitalism is how to resynchronise the speed of critique with that of its object. The idealised conception of a political system equal to participatory democracy, in the context of Chapter 4 on protest speeds, has been desynchronised from or alienated by economics systems. Basing her deductions on historical references and her interviews with OWS protesters, Kaun discusses the applicability of a resynchronisation theory, the Quadruple A-model, as brought up by Dieter Rucht, whose name refers to the terms "adaptation, abstention, attack and alternatives" (84-5). The lack of practices of abstention of speedy media technologies in real critical media activities indicates that "activists and their supporters need to re-politicize media technologies including social media, particularly in terms of their temporality" (95) in order to "resist a dominant discursive formation such as speed that is of interest" (85). Kaun sees the form of archiving protest movements as a resistant media practice for those activists themselves obtain a certain degree of autonomy in history writing (93).

In the concluding chapter, Kaun admits that crises and protest movements do provide alternatives. However, in the case of the Great Recession, there exists an alternative "form of creative destruction that allowed for the development of new business models and successfully linked the techno-optimism of Silicon Valley ideology with mainstream ideology" (99-100). The new business models that see the continuous 
updating of new data, such as a sharing economy based on social media, "often are not more than astroturfing for commercial purposes" (100). Critical media practices, due to their inevitable dependence on social media comprised of new business models, are therefore conditioned by the protest paradigm of the digital age, which "impedes lasting organizational structures" (102). However, Kaun writes that she does "not see an alternative in neglecting technology or an exclusive focus on slow media" (Ibid.). Instead, the examples of operational infrastructures such as TechOp show that there are still possibilities for alternative protest temporalities, though these infrastructures require "very specific skills and knowledge that alienates outsiders" (104).

This fascinating 130-plus-page book offers various intriguing, and perhaps even unique, perspectives in reviewing the recent history of American protest movements. It also explores the very insightful and valuable topic of how participatory democracy can be achieved in critical media practices in a digital age: a subject worth further continuous discussions.

To achieve "a democratic media activism" (105), besides exploring alternative media platforms with participation-encouraging affordances and properties, it is equally important to discuss how to change the fundamental production relationships of commercial media technologies in fast capitalism by mobilising and uniting all the self-conscious members of the dominated class, including the workers who "make high speed possible" in the first place (82). Apart from the urban protesters who are users and also content producers of social media, there are other types of labourers, such as assembly-line workers and programmers, who contribute to the reproduction of temporalities of media-technologies-time. Part of the reason that "[o]perational uses of technology provided by free software and open source activists remained overlooked" (103) is probably because the critique of protest media practices has not been thoroughly absorbed by all oppressed classes. And this fault in knowledge is partially caused by the global distribution of working classes.

Because of its focus on American history, Crisis and Critique contains only a limited examination of the international tendency of the desynchronisation between political timescales and capitalist temporality on the global scale. And in Chapter 3 , it is mentioned that "[t]he hyper-space biased ideology is closely connected to the ideology of globalization" (73), yet there is no further illustration on this equally important point. However, this does not deflect from the importance of this study and the author, who has "East German heritage and is now based in 'socialist' Sweden" (vii), and has provided a substantial alternative perspective on analysing American protest history.

As Kaun points out, the core problem of communicative capitalism lies in the contradiction between the temporality of media technologies and the time-consuming participation of the population or, in other words, the reification of time and space by capitalist technologies. The fundamental mechanism of communicative capitalism is embedded in the new imperialist expansion of globally over-accumulated capital through spatial fixes (see Harvey 2001). Therefore, the fast technologies of today's social media, which most protest media practices are based on, are a consequence of global production underpinned by cheap labour from the underdeveloped world, programmers from the developed world, and free users as content producers from all over the world.

There has, it seems to me, been a long-standing historical aggression towards international democratic socialism. According to the references in Crisis and Critique, in the 1930s communist activists taking part in hunger marches in America connected "local and national struggles to the international workers' movement" through 
their experiences travelling to Europe and the Soviet Union, and by the circulation of reports from the Soviet Union (64). Nowadays, not only has the participation of protests on social media become individualised, socialist protests by the international oppressed classes have grown increasingly isolated, affected by ever-growing nationalism in the global sphere. All in all, in circumstances where the international political agenda of communism is submerged by global neoliberal capitalism, it is of great importance to ensure a political critique in critical media practices, not only by exploring alternative media platforms but also by remaining cognizant of the totality of human society as a global village in order to address "institutional architectures, the production processes, content, media audiences and, most importantly, the cultural and structural environment of communication institutions that are clearly linked to broader political struggles" (105). 


\section{References}

Harvey, Davis. 2001. Globalization and the "Spatial Fix". Geographische Revue 2001(2): 2330. Accessed November 16, $2016 . \quad$ https://publishup.unipotsdam.de/files/2251/gr2 01 Ess02.pdf

Kaun, Anne. 2016. Crisis and Critique: A Brief History of Media Participation in Times of Crisis. London: Zed Books.

Virilio, Paul. 1986. Speed and Politics: An Essay on Dromology. New York: Semiotext(e). 